DOI: 10.17707/AgricultForest.62.1.27

\author{
Orhan YILMAZ, Y. Erdal ERTURK, \\ Fusun COSKUN, Mehmet ERTUGRUL ${ }^{1}$
}

\title{
SERICULTURE IN PROVINCES OF BURSA, AMASYA AND MUGLA (TURKEY)
}

\begin{abstract}
SUMMARY
Bursa was the important city where silkworm egg and cocoon were produced; silk and velvet were woven by hand and exported to the Europe in the period of Ottoman Empire. Since silkworm was brought to Anatolia, Bursa sustains its importance in this sector. Sericulture has begun at the same period in Amasya that is one of the Ottoman cities. Silks came from Iran were woven in this city because of being on Iran's trade route. The fabrics woven in Amasya were preferred by Ottoman Palace and also exported to the other countries. Sericulture and cocoon cultivating were made in Mugla the city has eligible climate condition to cultivate mulberry. Silk was woven by using simple bench as a family work. Bursa became rapidly an industrial city on silk texture because of having raw material by beginning of republic period. Silk texture has subsisted as a traditional Turkish handcraft at Amasya and Mugla.
\end{abstract} cocoon

Keywords: Bombyx mori, native breed, genetic resource, Silk Road,

\section{INTRODUCTION}

Some animal species and breeds had important place in history of some countries such as Merino sheep in Spain, Angora Goat in Turkey and sericulture in China (Ertugrul et al., 2010). Sericulture in the World is generally made in Asian countries. In the World production percentages of China and India are $80 \%$ and 15\% respectively (Kaya and Tutkun, 2012). The production of fresh cocoon is about 134 in 2012 (Table 1). Silk has some unique characteristics in kinds of fabric. It is shiny, soft, strong, and has a fabric can be dyed. It is so sensitive, therefore it is effected by noise, smell, wind, temperature change, even carers hygiene (Imer, 2005). Generally four kinds of silkworm which are Mulberry, Eri, Tasar and Muga are reared in the World. Mulberry silkworm (Bombyx mori) (Table 2) has the majority in them which percentage is about 95\% (Akbay,

\footnotetext{
${ }^{1}$ Orhan Yilmaz, (corresponding author: zileliorhan@gmail.com), Ardahan University, Vocational High School of Technical Sciences, Ardahan, TURKEY, Y. Erdal. Erturk, Igdir University, Faculty of Agriculture, Department of Agricultural Economics, Igdir, TURKEY, Fusun Coskun, Ahi Evran University, Faculty of Agriculture, Department of Animal Science, Kirsehir, TURKEY, Mehmet Ertugrul, Ankara University, Faculty of Agriculture, Department of Animal Science, Ankara, TURKEY

Paper presented at the $6^{\text {th }}$ International Scientific Agricultural Symposium "AGROSYM 2015 ".

Notes: The authors declare that they have no conflicts of interest. Authorship Form signed online.
} 
1981). In Turkish society silkworm seem cute. A survey study was realized in primary school students. According to study between 9 and $40 \%$ of students in different levels rear insects. Students rear silkworm, ant, ladybug and grasshopper which showed that silkworm was one the loveable insect in insect groups (Tezcan et al., 2010).

Table 1. Production of apiculture and sericulture (Anon 2010, 2013).

\begin{tabular}{|c|c|c|c|c|}
\hline Year & $\begin{array}{c}\text { Number of } \\
\text { Villages } \\
\text { Engaged in } \\
\text { Sericulture }\end{array}$ & $\begin{array}{c}\text { Number of } \\
\text { Families } \\
\text { Engaged in } \\
\text { Sericulture }\end{array}$ & $\begin{array}{c}\text { Number } \\
\text { of Egg Boxes } \\
\text { Produced }\end{array}$ & $\begin{array}{c}\text { Production } \\
\text { of Fresh } \\
\text { Cocoons } \\
\text { (tonnes) }\end{array}$ \\
\hline 1936 & 2.201 & 49.338 & 56.278 & 2.135 \\
\hline 1940 & 2.422 & 63.498 & 73.045 & 3.014 \\
\hline 1950 & 3.013 & 69.354 & 62.927 & 2.501 \\
\hline 1960 & 2.530 & 60.370 & 50.865 & 2.444 \\
\hline 1970 & 1.559 & 43.589 & 64.340 & 1.461 \\
\hline 1980 & 1.601 & 43.025 & 66.042 & 1.707 \\
\hline 1990 & 1.916 & 44.541 & 80.544 & 2.171 \\
\hline 2000 & 230 & 2.210 & 3.147 & 60 \\
\hline 2012 & 342 & 2.572 & 5.576 & 134 \\
\hline
\end{tabular}

Table 2. Scientific classification of the silkworm (Akbay, 1981).

\begin{tabular}{|c|c|}
\hline Phyluym & Artropoda \\
\hline Class & Insecta/Hexapoda \\
\hline Ordo & Lepidoptera \\
\hline Subordo & Macro Lepidoptera-Heterocera \\
\hline Super Family & Bomycoiden \\
\hline Family & Bomycidae \\
\hline Genus & Bombyx \\
\hline Species & B. mori \\
\hline
\end{tabular}

\section{Sericulture in Bursa}

Importance of Bursa in sericulture happened in 14th century during Ottoman Empire (Ergenc, 2013; Ersevinc, 2013; Inalcik, 2013, Kirayoglu, 2013a; Peker, 2013) but before there was a weaving industry before Bursa conquered in 1326 by Ottomans (Tas, 2013). The second important bazaar of floss silk trade was in Aleppo apart from Bursa. Persian merchants brought floss silk to Bursa and bought woollen from Europe, pearl from Persian Gulf, sugar from Egypt and Cyprus, and even spices from India. Even in 16th century Persian merchants used to sell floss silk in Bursa and bought tin, woollen and spices. Florence silk market used to decide prices depending on Bursa silk market (Ersevinc, 2013; Gunay, 2013; Inalcik, 2013). Schiltberger, Clavijo, Pero Tafur, and B. De le Broqiere reported that Bursa was one the most important floss silk bazaar in the World. 
Table 3. Travellers, writer, scientist and tourist visitors to Bursa and arrival dates (Ceyhan 2013)

\begin{tabular}{|c|c|c|c|}
\hline Name & Year of arrival & Name & Year of arrival \\
\hline Ibni Batuta & 1333 & George Keppel & 1830 \\
\hline Johann Hans Schiltberger & 1397 & Charles Texier & 1833 \\
\hline Bertrandon de La Broquiere & 1432 & Richard Burgess & 1834 \\
\hline Pero Tafur & 1437 & Duc de Raguse & 1834 \\
\hline Benedetto Dei & 1470 & Charles Greenstreet Addison & 1835 \\
\hline Bonsignore Bonsignore & 1498 & Aucher-Eloy & 1835 \\
\hline Bernardo Michelozzi & 1498 & William J. Hamilton & 1935 \\
\hline Arnold von Harf & 1496 & Julia Pardoe & 1836 \\
\hline Maringhi of Medici & Early $16^{\text {th }}$ century & Robert Walsh & 1836 \\
\hline Pierre Belon & 1546 & Edmund Spencer & 1836 \\
\hline Hans Dernschwam & 1555 & M. Baptistin Poujoulat & 1837 \\
\hline Stephan Gerlach & 1576 & Eliza C. A. Schneider & $1830-1840$ \\
\hline John Newberie & 1581 & Serafeddin Magmumi & 1894 \\
\hline George Chritoph Fedrenberger & 1588 & Hayrullah İbni Abdulhak & $1844,1851,1863$ \\
\hline Reinhold Lubenau & 1588 & G. W. Frederick Howard & 1853 \\
\hline Vincent Stochove & 1630 & Lean Henry Abdolone Ubicini & 1855 \\
\hline Evliya Celebi & 1640 & Kevork Keresteciyan & 1855 \\
\hline Jean-Baptiste Tavernier & $\begin{array}{l}\text { Several times } \\
\text { in his life }\end{array}$ & Sandison & 1855 \\
\hline Thevenot & 1666 & Charles James Monk & 1855 \\
\hline Spon & 1675 & Cyrus Hamlin & 1855 \\
\hline Covel & 1675 & Georges Perrot & 1856,1857 \\
\hline Wheler & 1675 & Journal de Constantinople & issue of Nov. 1863 \\
\hline Smith & 1683 & Sir Hubert E. H. Jerningham & 1870 \\
\hline Edmund Chishull & $\begin{array}{l}\text { at the end of } \\
17^{\text {th }} \text { century }\end{array}$ & Maling & betw. 1869-1872 \\
\hline Aubry de La Motraye & 1701 & Georgina Adelaide Muller & 1873 \\
\hline Joseph Pitton de Tournefort & 1701 & Henry C. Barkley & 1878 \\
\hline Paul Lucas & 1702 and 1705 & Nikola Nachov & 1879 \\
\hline Richard Pococke & 1738 & Edmond Dutemple & 1880 \\
\hline Carsten Niebuhr & 1767 & Marie de Launay & 1880 \\
\hline Dominique Sestini & 1779 & Omer Suphi & 1889 \\
\hline Andre-Joseph Lafitte-Clave & 1786 & Ibnulcemal Abdul Tevfik & $1890 \mathrm{~s}$ \\
\hline Le Chevalier & 1786 & Clement Imbalt Huart & 1891 \\
\hline William Hunter & 1792 & Mehmet Ziya & $1892-1893$ \\
\hline Guillaume Antoine Olivier & 1790 & Fatma Fahrunnisa & 1895 \\
\hline Von Ignatz von Brenner & 1793 & Paul Lindau & 1897 \\
\hline James Dallaway & 1794 & Vasil Kinchev & 1899 \\
\hline Antonie Galland & $\begin{array}{l}\text { at the beginnig } \\
\text { of } 18^{\text {th }} \text { century }\end{array}$ & Osmanzade Huseyin Vassaf & 1901 \\
\hline William George Browne & 1802 & Regis Delbauf & 1905 \\
\hline Joseph von Hammer-Purgstall & 1804 & Richard Davey & 1906 \\
\hline Lady Hester Stanhope & 1811 & Hasan Taib & 1907 \\
\hline Christophe Aubin & 1812 & Paul Fesch & 1907 \\
\hline John MacDonald Kinneir & 1813 and 1814 & P. N. Daskalov & 1909 \\
\hline John Fuller & 1818 & Kethy Brown & 1911 \\
\hline Charles MacFarlene & $1820 \mathrm{~s}$ & Andre Gide & 1914 \\
\hline Victor Fontainer & 1821 & Ewald Banse & 1918 \\
\hline William Martin Leake & 1824 & Grace M. Ellison & 1924 \\
\hline Joseph-Marie Jouannin & 1825 & Clare Consuelo Sheridan & 1924-1925 \\
\hline
\end{tabular}


After floss silk was imported to Bursa, it was drawn in filature factories and woven textile factories, after than it was exported to Europe (Ergenc, 2013). In history of Bursa lots of travellers, writer, scientist and tourist visited the city and mentione about sericulture in Bursa (Table 3). For example Heat Lowry mentioned in his book of 'Seyyahlarin Gozuyle Bursa' (Bursa from Travellers Eyes) about 60 travellers who visited Bursa. There were some special profession on this sector. 'Hamcilar' used to draw silk fibres from cocoon by using tool of 'mancinik' and after thansilk fibres are made silk thread by using tool of 'dolap' (Karaarslan, 2013). Silk thread was dyed by 'boyacilar' and later than dyed silk tread was woven by 'dokumacilar'. (Ergenc, 2013; Oguzoglu, 2013). By depending on their work experience, dokumacilar were into three groups called as 'cirak', 'kalfa', and 'usta'. Cirak which meant apprentice was a beginner. If a cirak works 1001 days in this work, they are promoted as kalfawhich meant headworker. After a kalfa worked several years, he was tested by a commission and became an usta which meant 'master' (Tas, 2013).Women generally used to work in filature factories rather that weaving factories. Girlscommonly used to work until they mary to gain dowry money. After girls mary, they leave the job (Akkus, 2013, Soysaldi and Ozdemir, 2013).

The various kinds of woven fabric were named in different names such as 'arsin, dip, seraser, dosemelik, carsaflik, cekme, sestari, hakir, keyfiye, ipekli abani, ipek hayten, sacak, serit, oya, puskul, kemha, atlas, kutnu, futa, kadife (velvet), tafta, cifte tafta, yigit tafta, and vale (Oguzoglu, 2013; Turkoz, 2013). Bursa Olgunlasma Enstitusu (Maturation Institute of Bursa)is established in Bursa in 2007 to educate girls on native cultural items. In the school girls are educated on lots of kinds of woven silk fabric mentioned above (Goral, 2013; Kemankas, 2013) Florentiner Maringhi reported that quality of silk fabric definitely much more better than silk fabric made in China (Turkoz, 2013). In order to obtain different kinds of colours, silk fabric was dyed. There were used plenty of plants to dye fabric. Yellow colour was obtained from 'Altin agac, Katirtirnagi (Spartium - Spartium junceum), sumak (sumac), gence, and safran (saffron)'. Brown colour was obtained from 'mazi' (thuja), 'mese' (oak), 'ceviz ve yapragi' (walnut and walnut leaves).Red was obtained from 'pine bark' and 'kokboya' (madder), green colour from 'yabani nane' (wild mint), blue colour from 'Hint bitkisi', gray colour from sutlegen (spurge, Euphorbia)', black colour from combination of 'karpuz otu' and 'kara dal otu'(Oguzoglu, 2013).

After steam engine invented in Lyon in 1824, a French family, Glaizal Family, built a filature factory in Bursa in 1837 but after for a while this factory went bankrupt (Basaran, 2013; Ciftci, 2013). Austrian consul of Falkheisen bought the factory. He reopened the factory in 1945 together with Tasciyan who was a Ottoman Empire citizen and work in British consulate as a translator. After this filature factory, sericulture industry developed in Bursa region. (DortokAbaci, 2006; Cakici, 2013; Ciftci, 2013). For example in 19th centurythere were 130.000 families who reared silkworm. This number increased to 150.000 families in 1900s. Also about 19.000 employee worked in filature sector and 
2.000 employee in textile sector (Altun 2013). Steam engine filature factories used to need high amount of firewood. This firewood was brought from Ulu Mountain which was the nearest mountain in Bursa region via Nilufer River. In late 19th century although firewood requirement was about 15.000 tonnes for filature factories, it was just about 5.000 tonnes for whole Bursa people at homes (Ciftci, 2013).

In Bursa there were lots of spesific bazaars or markets depending on goods sold such asBakircilar Carsisi (for coppersmiths), Oduncular Pazari (for firewood), Yemeniciler Carsisi (for shoes), (Pirinc Han (for rice), Tahil Han (for grains), and Tuz Han (for salt). Ipek Han (for floss silk), and Koza Han (for cocoon) were two of those spesific places (Kirayoglu, 2013a,b)

\section{Sericulture in Amasya}

Apart from Bursa, Amasya region is one the most important sericulture centres in Turkey(Kivrim and Elmaci, 2011; Yucekaya, 2013). Amasya is also hometown of Strabon (B.C. 64/63 - A.D. 24) who was a famous historian, geographer and philosopher (Anon 2014). Climate conditions of Amasya is very eligible for sericulture and looks like Bursa climate. On the other hand Amasya had a strategic position on way of Anatolian roads in Ancient time and still has. Amasya was on way of the Silk Road from Iran to Bursa (Gunay, 2013; Kivrim and Elmaci, 2011). There is a village named as Ipek Koy (Silk Village in English) which is $9 \mathrm{~km}$ far from Amasya city centre (Kivrim and Elmaci, 2011). It can be said that history of sericulture in Amasya is old as history of sericulture in Ottoman Empire (Yucekaya, 2013). During Ottoman King of Selim I there was a war between Ottomans and Iran. The King Selim I put into action of embargo for silk trade between Ottomans and Iran. During this embargo Amasya was one of the most important sericulture centre for export silk material in Bursa silk market. In different times Amasya sent some sericulture experts to other cities. For example Bor county demanded 8-10 families who were expert on sericulture and Amasya approved this wish. Ispir county demanded some experts for sericulture (Kivrim and Elmaci, 2011). In Amasya there was established a Sericulture Station in 1921 (Colak, 2013).

\section{Sericulture in Mugla}

The Province of Mugla is located at southeast of Anatolia. It has a mild climate and eligible for mulberry cultivation and sericulture. Textile industry was based on sericulture and it had important for economy of Mugla. There are made famous 'duven' fabric in Yesilyurt town and Mugla city centre. Sericulture in Mugla is a tradational family business. Mugla region used to be a closed economy because of some deficiencies about transport and geographic conditions. Sericulture is generally made by women, so they invest to buy gold jevelry for theirself income of sericulture. After 1950s, economy of Mugla opened to outer bazaars. People started to deal with different kinds of business, so then sericulture business decreased. In 1970s tobacco cultivation started to be supported by governments and people cut mulberry trees and started to cultivate tobacco like Bursa immagrants who came from Greece in 1924 (Colak, 2013). 


\section{CONCLUSIONS}

Bursa is regarded as one of big centers in that silk trade an industry in history (Inalc1k 2013). Anatolia, especially Busa was an very important station silk road in 15th and 16th century. Silk trade between Europe and Asia was made through Bursa. On that period Bursa became an entrepot city where the silk that came from Iran was weighted, stored and taxed (Sahan 2013). Sericulture in Bursa had big changes in 19th century. Modern catapult texture industry was begun to use instead of classical hand-made texture. Amount of silk product increased significanly by using mechanical industry. By the changes of wold textile industry, mechanized mass production was begun to use instead of handmade and fine workmanship production. Then, cotton fabrics especially English cotton was begun to use rather than silky fabrics (Altun 2007). On the contrary Bursa was efficient on silk industry in that period when a lot of factory were established, a lot of people studied at new schools and specialized in sericulturing. Bursa has significant role on worldwide textile industry because of having big economical potential of silk texture industry (Altun 2007). However silk texture exists as a Turkish traditional handcraft in Amasya and Mugla.

\section{REFERENCES}

Akbay, R. 1981. Ipekbocegi Yetistirme. Ankara Universitesi, Ziraat Facultesi, Ders Notlari, 54. Ankara.

Akkus, T. 2013. Bursa Ipekciliginde Gayrimuslimler. Bursa'da Yasam Dergisi, Aralik: 136-147.

Altun, D. 2007. XIX. Yuzyilda Bursa'da Ipek Bocekciligi. Balikesir Universitesi, Fen Edebiyat Fakultesi Tarih Kulubu Bulteni, 2007/1: 102-108.

Altun, D. 2013. Ipekbocekciligin Sosyal Yasama Etkisi. Bursa'da Yasam Dergisi, Aralik: 118-125.

Anonymous. 2010. Statistical Year Book 2010. Turkish Statistical Institute, Prime Ministry: Ankara.

Anonymous. 2013. Livestock Statistics, Statistics by Theme. Turkish Statistical Institute, Prime Ministry, Ankara. (accessed on 3.1.2014)

Anonymous. 2014. Strabon. http://en.wikipedia.org/wiki/Strabon (accessed on 15.01.2014)

Basaran, H. Z. 2013. Bursa Ipekciliginde Kadinlari Rolu. Bursa'da Yasam Dergisi, Aralik: 114-117.

Ceyhan, A. 2013. Seyyahlarin Dilinden Bursa'da Ipek. Bursa'da Yasam Dergisi, Aralik: 364-385.

Cakici, M. 2013. Bursa IpekCekim Fabrikasi ve İstihdam Sorunu (1851-1873). Bursa'da Yasam Dergisi, Aralik: 56-66.

Ciftci, C. 2013. Bursa'da IpekCekim Fabrikalarinin Kurulmasi. Bursa'da Yasam Dergisi, Aralik: 50-53.

Colak, C. 2013. Cumhuriyet Doneminde Mugla'da Ipekbocekciligi Ve Ipekli Dokumacilik (1923 - 1970). Mugla Universitesi, Sosyal Bilimler Enstitusu Dergisi, 8: 81-97.

Dortok-Abaci, Z. 2006. Bursa Economy According to the British Consular Reports (1848-1896). UludagUniversitesi, Fen Edebiyat Fakultesi, Sosyal Bilimler Dergisi, 2006/2, 7 (11): 159-171. 
Ergenc, O. 2013. Bursa'da Ipekli Dokumacilik. Bursa'da Yasam Dergisi, Aralik: 28-30.

Ersevinc, M. 2013. 19-20. Yuzyillarda Bursa'da Ipekcilik. Bursa'da Yasam Dergisi, Aralik: 92-101.

Ertugrul, M., Dellal, G., Elmaci, C., Akin, A. O., Pehlivan, E., Soysal, M. I. \& Arat, S. 2010. Conservation Of Farm Animal Genetic Resources And Their Sustainable Use. Turkish Agricultural Engineering Technical Congress VII, 11-15 January 2010. Ankara.

Goral, D. 2013. Olgunlasma Enstitusu. Bursa'da Yasam Dergisi, Aralik: 322-329.

Gunay, N. A. 2013. Yavuz Sultan Selim'in Ipek Ambargosu. Bursa'da Yasam Dergisi, Aralik: 166-173.

Imer, Z. 2005. Miladi Donem Oncesinde Orta Asya'da Ipek. Bilig, Turk Dunyasi Sosyal Bilimler Dergisi, 32: 1-32.

Inalcik, H. 2013. Bursa ve Ipek Ticareti. Bursa'da Yasam Dergisi, Aralik: 22-25.

Karaarslan, Y. Z. 2013. Osmanli Semti Muradiye'de Ipekcilik. Bursa'da Yasam Dergisi, Aralik: 102-107.

Kaya, R. and Tutkun, M. 2012. Turkiye'de Ipekbocekciligi. 8th National Congress of Animal Science Students, 22-23 May 2012, Sanliurfa.

Kemankas, I. 2013. Dunyanin En Uzun Hatli Teleferigi Bursa'da. Bursa'da Yasam Dergisi, Aralik: 420-425.

Kirayoglu, K. 2013a. Bursa'da Ticaret ve Mekan. Bursa'da Yasam Dergisi, Aralik: 174179.

Kirayoglu, M. 2013b. IpekSehri Bursa'da Carsinin Olusumu. Bursa'da Yasam Dergisi, Aralik: 84-91.

Kivrim, I. ve Elmaci, S. 2011. Amasya Sericulture in Ottoman Period. Turkish Studies, 6/4: 715-728.

Oguzoglu, Y. 2013. Bursa Uygulanan Ipek Dokuma Teknolojileri. Bursa'da Yasam Dergisi, Aralik: 56-66.

Peker, E. H. 2013. Bursa Ipekciliginden Bir Kesit. Bursa'da Yasam Dergisi, Aralik: 266273.

Soysaldi, A. ve Ozdemir, H. A. 2013. Bursa Kiz Ceyizinde Ipegin Yeri. Bursa'da Yasam Dergisi, Aralik: 156-165.

Sahan, U. 2013. Gecmisten Gunumuze İpekböceği Yetiştiriciligi ve İpekcilik. Bursa'da Yasam Dergisi, Aralik: 40-46.

Tas, H. 2013. Bursa Folklorunda Ipek ve Koza. Bursa'da Yasam Dergisi, Aralik: 136147. 